\title{
Analisis Penerapan Kurikulum 2013 Dalam Meningkatkan Kualitas Pembelajaran Masa Pandemik Covid-19 di SMAN 3 Kota Bima
}

\author{
Amiruddin', Irma Rubianti², Nikman Azmin ${ }^{3 *}$, Muh. Nasir ${ }^{4}$, Ahmad Sandi ${ }^{5}$ \\ ${ }^{12345}$ Dosen Sekolah Tinggi Keguruan dan Ilmu Pendidikan (STKIP) Bima \\ Email: biologinikman@gmail.com
}

\begin{abstract}
Abstrak
Penelitian ini bertujuan untuk menganalisis penerapan kurikulum 2013 dalam meningkatkan kualitas pembelajaran masa pandemik Covid-19 di SMAN 3 Kota Bima. Metode yang digunakan adalah dengan menggunakan metode deskriptif untuk mengetahui analisis perencanaan dan pelaksanaankurikulum 2013 yang dilakukan oleh guru dalam pelaksanaan dan peningkatan pembelajaran pada masa pandemic covid-19 di SMAN 3 Kota Bima. Hasil Penelitian menunjukan bahwa penerapan Kurikulum 2013 masa pandemi Covid-19 di SMAN 3 Kota Bima tidak maksimal hanya berjalan 50 persen, hal ini disebabkan oleh situasi pandemik Covid-19 yang tengah melanda dunia termasuk Indonesia, yang mana hal itu merusak seluruh sektor termasuk pendidikan.Penerapan Kurikulum 2013 di masa pandemi Covid-19 ini sangat sulit untuk diterapkan, selain karena susahnya belajar melalui komunikasi jarak jauh juga tidaksemua siswa dapat mengikutinya dikarenakan masalah waktu, tempat, dan biaya bagi orang tua. Hal ini berdampak besar bagi perkembangan kemampuan siswa di sekolah. Guru tidak bisa secara maksimal melihat perkembangan siswa,akibatnya siswa tidak dapat mencapai target kurikulum nasional dan kurikulum sekolah.
\end{abstract}

Kata Kunci: Analisis Penerapan Kurikulum 2013, Pembelajaran Daring.

\section{PENDAHULUAN}

Dunia pendidikan sekarang dituntut untuk Kurikulum merupakan sebuah hal yang penting bagi berjalannya kegiatan pendidikan. Tanpa kurikulum pendidikan tidak akan berlangsung dengan baik sesuai apa yang diinginkan. UU No. 20 Tahun 2003 'tentang Sistem Pendidikan Nasional kurikulum adalah seperangkat rencana dan pengaturan sebagai pedoman penyelenggaraan kegiatan proses pembelajaran (Kurniaman, 2017).

Kurikulum 2013 dipakai sejak tahun ajaran 2013 dalam Sistem Pendidikan Indonesia. Kurikulum 2013 adalah kelanjutan dan penyempurna Kurikulum Berbasis Kompetensi dan Kurikulum Tingkat Satuan Pendidikan. Kurikulum 2013 ini sudah berjalan hingga tahun 2013-2019 namun menjadi sebuah problem semenjak adanya Covid-19 yang melanda seluruh dunia tanpa terkecuali Indonesia. Pemerintah menerapkan kebijakan baru terkait untuk memutuskan mata rantai virus dan menerapkan kebijakan berskala besar sosial distancing. Hampir semuanya berdampak tidak terkecuali bidang pendidikan, dan pemerintah mengganti model pembelajaran di sekolah ataupun di perguruan tinggi sejak 16 Mei 2020 sampai waktu yang akan diberitahukan lebih lanjut. Pandemi ini memaksa belajar mengajar di sekolah yang biasanya langsung berubah menjadi daring. Tentunya beberapa pihak tidak siap akan hal pembelajaran secara online, baik guru, siswa maupun orang tua. Apalagi jika harus menerapkan sistem kurikulum 2013 yang kompleks dalam pembelajaran online.

Penerapan kurikulum 2013, bahwa setiap mata pelajaran meliputi tiga kompetensi, yaitu pengetahuan, sikap dan keterampilan. Hal ini tidak mudah dilakukan jika tidak secara tatap muka. Hambatan lainnya juga ialah kurangnya infrastruktur pendukung pembelajaran online itu sendiri. Maka ketidak tercapaiannya menjalankan kurikulum 2013 dalam pembelajaran online atau daring. Belum lagi kendala yang di rasakan oleh orang tua siswa yang ekonominya tidak semua berada diatas, ada yang sebagian menengah kebawah sehingga tidak dapat menyediakan fasilitas pembelajaran online atau daring seperti kuota internet. Sehingga banyak kendala yang dirasakan dalam melakukan penerap kurikulum 2013 yang mengakibatkan pembelajaran kurang efektif dan efesien (Masrokhah, 2020).

Sistem pendidikan kontemporer sangat mendesak untuk melalui inovasi baru untuk setiap bidang. Semua negara maju dan berkembang lebih berkonsentrasi pada penelitian dan pengembangan; sebagai hasilnya, teknologi adalah bagian dari setiap kurikulum disemua tingkatan (Azmin dan Nasir, 2019). 
Sebuah negara seperti India ingin memperkenalkan lebih banyak berbasis web baru kursus bagi siswa agar sesuai dengan mereka ke dalam pasar kerja global. Para pelajar saat ini sangat termotivasi oleh eksposur internasional. Inovasi teknologi sangat berpengaruh dalam masyarakat ini.Teknologi memungkinkan kita mempelajari semua hal dan memberikan kesempatan untuk memanfaatkan teknologi tanpa diskriminasi. Didalam konteksnya, penting untuk memahami elearning membawa perubahan social (Radha dkk, 2020).

SMA Negeri 3 Kota Bima adalah salah satu sekolah menengah yang melaksanakan Kurikulum 2013 dimasa pandemik dan merupakan salah satu sekolah percontohan dalam pelaksanaan Kurikulum 2013 di Kota Bima pada tahun ajaran 2019/2020 guna meningkatkan prestasi siswanya. Penerapan Kurikulum 2013 pada SMA Negeri 3 Kota Bima sudah berjalan. Dalam pra observasi yang telah dilakukan oleh peneliti, didapatkan hasil bahwa, pembelajaran dengan menggunakan Kurikulum 2013 dapat dilakukan dengan baik walaupun ada beberapa kendala yang dialami oleh para guru. Sebagian guru menyebutkan bahwa Kurikulum 2013 mudah untuk diterapkan, lebih baik dan efektif untuk digunakan, namun ada guru menyebutkan bahwa Kurikulum 2013 kurang pas apabila diterapkan pada mata pelajaran bersifat praktek terutama pada masa pandemik karena pelajaran praktek sulit diterapkan dengan metode pembelajaran scientific approach, project based learning, discovery learning. Selain itu, guru juga mengungkapkan bahwa pemahaman guru terhadap esensi Kurikulum 2013 masih kurang sehingga penerapan dalam kelas kurang maksimal. Sosialisasi dan pelatihan yang belum maksimal membuat para guru hanya melaksanakan Kurikulum 2013 menurut apa yang mereka ketahui saja.

\section{METODE}

Metode yang dipakai dalam penelitian ini adalah metode kualitatif, metode ini dipilih karena bertujuan untuk menetukan cara mencari, mengumpulkan, mengolah, dan menganalisis data dari hasil penelitian tersebut. jenis pendekatan metode yang digunakan dalam penelitian ini adalah metode deskriptif. Metode pengumpulan data yang digunakan yaitu wawancara mendalam, dokumentasi yakni meneliti dokumen-dokumen dalam bentuk buku, literatur maupun jurnal-jurnal ilmiah yang berkaitan dengan penelitian. Adapun tujuan studi dokumen atau teks yaitu untuk mengkaji tingkat keterbacaan sebuah teks, atau untuk menentukan tingkat pencapaian pemahaman terhadap topik tertentu dari sebuah teks. Dalam penelitian ini, peneliti berusaha memahami bagaimana analisis penerapan kurikulum 2013 dalam meningkatkan kualitas pembelajaran di SMAN 3 Kota Bima. Data yang diambil dalam penelitian ini berasal dari berbagai sumber dan hasil penelitian yang bersangkutan dengan kasus yang diselidiki.

\section{HASIL DAN PEMBAHASAN}

\section{A. Kebijakan Pemerintah Pembelajaran Kurikulum 2013 Melalui Daring di Masa Pandemi Covid-19}

Penutupan institusi pendidikan akibat merebaknya Covid-19 mengakibatkan dampak buruk dalam dunia pendidikan. Selama lockdown, guru diinstruksikan untuk mengajar melalui media pembelajaran online. Raju mengatakan bahwa ada kebutuhan untuk mengadopsi pengajaran yang inovatif untuk melanjutkan pendidikan dan mengatasi tekanan mental dan kecemasan. Wabah Covid-19 menyebabkan revolusi digital dalam sistem pendidikan tinggi melalui ceramah online, telekonferensi, buku terbuka digital, ujian online, dan interaksi di lingkungan virtual. Dampak positif dari Covid-19 juga melaporkan efisiensi dan kinerja pembelajaran dengan mengadopsi strategi pembelajaran online. Mode online dari proses belajar mengajar acapkali diskriminatif bagi siswa miskin dan terpinggirkan. Teridentifikasi bahwa siswa tunarungu menghadapi tantangan dalam system pembelajaran online. Selama masa lockdown ini, penutupan semua institusi pendidikan menghambat sistem pendidikan dan proses belajar mengajar. Memahami proses belajarmengajar dalam periode krisis ini sangat penting untuk merancang efektifitas untuk kelancaran 
pengajaran dan pembelajaran (Kapasia dkk, 2020).

Masa pandemi Covid-19 mempengaruhi hampir semua aspek kehidupan, tak terkecuali aspek pendidikan. Untuk memutus mata rantai penyebaran Covid-19 semua siswa di berbagai Negara meniadakan kegiatan di sekolah. Hingga April 2020, lebih 400 juta siswa di dunia diwajibkan untuk belajar di rumah. Konsekuensi dari penutupan Lembaga Pendidikan secara fisik dan mengganti dengan belajar dari rumah sebagaimana kebijakan pemerintah adalah adanya perubahan sistem belajar mengajar yaitu berimigrasi ke sistem digital, yang dikenal dengan pembelajaran daring (Sudarsana dkk, 2020). Negara Indonesia juga melakukannya meskipun menyadari bahwa ada disparitas terhadap akses teknologi pembelajaran dan beragamnya latar belakang orang tua.

Perubahan pola belajar mengajar tak terlepas dari peran guru, guru harus siap dengan berbagai kondisi pembelajaran dan kondisi siswa, termasuk perkembangan kehidupan di masyarakat (Wahyono dkk, 2020). Kendatipun pembelajaran tatap muka memiliki banyak kelebiha bagi pengajar dan peserta didik, tetapi pandemi Covid-19 mengharuskan guru melakukan aktivitas pembelajaran melalui pembelajaran Daring. Pembelajaran daring memerlukan kreativitas pendidik, sehingga transfer ilmu pengetahuan dan keterampilan berjalan baik. Pendidik wajib menguasai cara penggunaan komunikasi dalam jaringan, yakni berkomunikasi lewat jaringan internet. Sebab adanya pandemi Covid-19 aktivitas pembelajaran dari rumah dengan metode online. Pembelajaran daring disesuaikan dengan kemampuan sekolah masing-masing. Belajar daring bisa mengguakan teknologi seperti whats app dan lainnya. Tapi yang mesti dilakukan anak dipastikan belajar. Lalu para guru berkoordinasi dengan orang tua (Azmin dan Nasir, 2019). Di sebagian daerah proses belajar dari rumah telah dilakukan sejak 16 Maret 2020 dan diperpanjang setelah memperhatikan kondisi pada daerah masing- masing. Pendidik dan peseta dididik banyak yang menjadi terpaksa harus siap menghadapi pembelajaran model belajar daring. Sebagian sekolah ada yang sudah terbiasa memakai teknologi pada kegiatan belajar mengajar, namun menjadi kendala bagi sekolah yang tidak pernah menyelenggarakan pembelajaran daring, terutama di daerah terpencil (Arifa, 2020).

Dalam situasi Covid-19 kurikulum adalah sebuah hal yang harus disesuaikan dengan keadaan. Kurikulum harus disederhanakan atau seorang pendidikan tidak mesti senantiasa berinteraksi sehingga pembelajaran disesuaikan dengan bagaimana sekolah dan murid berada. Pendidik diharapkan bisa melaksanakan pembelajaran yang bervariasi seperti menentukan kompetensi dasar dan materi untuk disederhanakan. Para pendidik diharapkan melaksanakan inovasi pembelajaran tanpa meninggalkan prinsip pembelajaran dari rumah di masa pandemi Covid-19 (Gusty dkk, 2020).

\section{B. Analisis Pelaksanaan Kurikulum 2013 di SMAN 3 Kota Bima}

Penerapan kurikulum 2013 di masa pandemi COVID-19 di SMAN 3 Kota Bima adalah mencakup beberapa aspek sebagai berikut: Berdasarkan temuan data bahwa penerapan kurikulum 2013 selama pandemi Covid-19 SMAN 3 Kota Bima adalah berdasarkan aturan dari surat edaran Kemendikbud No. 4 Tahun 2020 bahwa melaksanakan proses belajar dari rumah melalui pembelajaran daring tanpa membebani tuntutan menuntaskan seluruh capaian kurikulum untuk kenaikan kelas maupun kelulusan (Kurniaman, 2017). Berdasarkan surat tersebut SMAN 3 Kota Bima mengeluarkan aturan pelaksanaan daring untuk semua siswa yang berjumlah 216 siswa yang terdiri dari: 5 rombel untuk kelas 7,4 rombel untuk kelas 8 , dan 6 rombel untuk kelas 9 dan kepada semua guru yang berjumlah 75 orang. Namun teknis pelaksanaannya di atur oleh kepala sekolah. Adapun teknisnya dalam Tabel 1 sebagai berikut:

Tabel 1. Tehnik Pelaksanaan Kurikulum 2013 di Sekolah SMAN 3 Kota Bima

\begin{tabular}{|c|c|c|}
\hline $\begin{array}{c}\text { Penerapan } \\
\text { Kurikulum } \\
\mathbf{2 0 1 3}\end{array}$ & $\begin{array}{c}\text { Teknis } \\
\text { Pelaksanaan }\end{array}$ & $\begin{array}{c}\text { Waktu } \\
\text { Pelaksanaan }\end{array}$ \\
\hline $\begin{array}{l}\text { Pembelajaran } \\
\text { dilakukan } \\
\text { secara daring } \\
\text { dengan } \\
\text { menggunakan } \\
\text { jaringan }\end{array}$ & $\begin{array}{l}\text { Wali kelas } \\
\text { bersama } \\
\text { dengan } \\
\text { orang tua } \\
\text { membuat } \\
\text { sebuah }\end{array}$ & $\begin{array}{l}\text { Semenjak keluar } \\
\text { edaran } \\
\text { Kemendikbud } \\
\text { terkait } \\
\text { pembelajaran } \\
\text { daring }\end{array}$ \\
\hline
\end{tabular}




\begin{tabular}{|c|c|c|}
\hline internet & $\begin{array}{l}\text { group } \\
\text { Whatsapp }\end{array}$ & \\
\hline $\begin{array}{l}\text { Metode } \\
\text { pembelajaran } \\
\text { dilakukan } \\
\text { dengandua } \\
\text { cara, yaitu } \\
\text { luringdan } \\
\text { daring }\end{array}$ & $\begin{array}{l}\text { 1. Luring, } \\
\text { yaitu } \\
\text { mengunda } \\
\text { ng siswa } \\
\text { kesekolah } \\
\text { bagi orang } \\
\text { tuayang } \\
\text { mengizink } \\
\text { ananaknya } \\
\text { konsultasi, } \\
\text { dan } \\
\text { 2. Daring, } \\
\text { yaitu } \\
\text { mengadak } \\
\text { an } \\
\text { pembelajar } \\
\text { an jarak } \\
\text { jauh } \\
\text { mengguna } \\
\text { kan } \\
\text { aplikasi } \\
\text { google } \\
\text { classroom } \\
\text { dan Video } \\
\text { Call } \\
\text { Whatsapp }\end{array}$ & 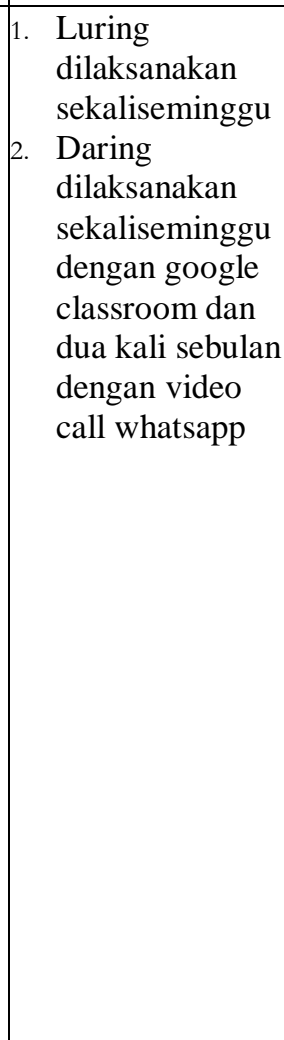 \\
\hline $\begin{array}{l}\text { Evaluasi } \\
\text { perkembanga } \\
\text { n siswa }\end{array}$ & $\begin{array}{l}\text { Mengevalua } \\
\text { si } \\
\text { perkembang } \\
\text { an siswa } \\
\text { terkait } \\
\text { kondisi } \\
\text { siswadan } \\
\text { lokasi } \\
\text { rumahnya } \\
\text { dari virus } \\
\text { COVID-19 }\end{array}$ & $\begin{array}{l}\text { Pertemuan } 1 \mathrm{x} \\
\text { seminggu }\end{array}$ \\
\hline $\begin{array}{l}\text { Mengintegras } \\
\text { ikan dengan } \\
\text { kurikulum }\end{array}$ & $\begin{array}{l}\text { Menjelaskan } \\
\text { Ulang } \\
\text { materi yang } \\
\text { ditugaskan }\end{array}$ & $\begin{array}{c}\text { Pertemuan } 1 \mathrm{x} \\
\text { seminggu }\end{array}$ \\
\hline
\end{tabular}

Dari tabel 1 diatas diketahui bahwa pembelajaran di SMAN 3 Kota Bima pada masa pandemi Covid-19 dilakukan secara daring dengan menggunakan jaringan internet. Wali kelas bersama dengan orang tua membuat sebuah group Whatsapp agar memudahkan terjadinya komunikasi dan pembelajaran jarak jauh Antara siswa yang diawasi orang tua dengan guru di sekolah

Metode pembelajaran dilakukan dengan dua cara, yaitu luring dan daring:

1. Luring, yaitu mengundang siswa bagi orang tua yang mengizinkan anaknya konsultasi. Mengadakan pertemuan secara tatap muka langsung dengan siswa datang ke sekolah teruntuk bagi orang tua yang mengizinkan dengan ketentuan durasi waktu dan mentaati protokol kesehatan. Pembelajaran kombinasi yang diizinkan pemerintah, pihak sekolah tidak melarang siswa untuk datang ke sekolah namun membatasi skala jumlahnya dengan ketentuan sekali seminggu dating ke sekolah dan maksimal 6 orang perkelas.

2. During, yaitu mengadakan pembelajaran jarak jauh menggunakan aplikasi google classroom dengan memberikan materi dan mengadakan quiz agar siswa tidak stress jika hanya diberikan tugas. Juga melakukan pembelajaran virtual minimal dua kali sebulan, guru memberikan materi melalui video dari rumah kemudian ditonton oleh siswa yang didampingi oleh orang tua di rumah sebab masih bingung dengan materi dan tugas yang diberikan oleh karena itu perlu diadakan sistem tatap muka online. Tidak serta merta siswa belajar hanya melalui google classroom sebab siswa tidak mengerti walaupun terkadang telah didampingi bersama orang tua maka sekolah bertanggung jawab untuk pencapaian target siswa.

3. Setiap pekan dilakukan evaluasi apakah siswa tinggal diclaster Covid-19. Jika diketahui tempatnya closter Covid-19 sementara orang tua mengizinkan ke sekolah maka akan ditolak, sebab siswa harus menjalani isolasi mandiri dan melakukan pembelajaran dari rumah, kendatipun tidak positif terkena Covid- 19

\section{KESIMPULAN}

Dari hasil penelitian terhadap Analisis penerapan Kurikulum 2013 di masa pandemi Covid-19 di SMAN 3 Kota Bima tidak maksimal hanya berjalan 50 persen. Hal ini disebabkan situasi pandemi Covid-19 yang tengah melanda dunia termasuk Indonesia, yang mana hal itu merusak seluruh sektor termasuk pendidikan. Penerapan Kurikulum 2013 di masa pandemi Covid-19 ini sangat sulit untuk diterapkan, selain karena susahnya belajar melalui komunikasi jarak jauh juga 
tidak semua siswa dapat mengikutinya dikarenakan masalah waktu, tempat, dan biaya bagi orang tua. Hal ini berdampak besar bagi perkembangan kemampuan siswa di SMAN 3 Kota Bima. Guru tidak bisa secara maksimal melihat perkembangan siswa, akibatnya siswa tidak dapat mencapai target kurikulum nasional dan kurikulum sekolah.

\section{SARAN}

Adapun saran-saran yang dapat dikemukakan oleh peneliti dari hasil penelitian ini adalah sebagai berikut:

1. Pemanfaatan email dan whatsApp dengan penggunaan fitur yang ada sangat membantu dalam proses pembelajaran, tetapi pelaksanaan ini kurang efektif karena tidak semua materi yang disampaikan dipahami dengan baik.

2. Bagi guru perlunya peningkatan kompetensi guru mengenai penggunaan TIK, sehingga kesiapan kegiatan pembelajaran dengan menggunakan teknologi seperti saat ini dapat lebih dimaksimalkan.

\section{UCAPAN TERIMA KASIH (12pt)}

Ucapan terima kasih kami sampaikan pada kemenristikdikti/kemendikbud RI yang telah mendanai penelitian ini sampai selesai dan semua tim telah membantu dan Kepala sekolah sman 3 Kota Bima yang telah membantu dan mengizinkan kami untuk melakukan penelitian.

\section{DAFTAR PUSTAKA}

Arifa, F. N. 2020. Tantangan Pelaksanaan Kebijakan Belajar Dari Rumah Dalam Masa Darurat Covid-19. Info Singkat;Kajian Singkat Terhadap Isu Aktual Dan Strategis

Azmin, N., \& Nasir, M. (2019). Penerapan Model Pembelajaran 5E Untuk Meningkatkan Keterampilan Proses Sains Dan Sikap Ilmiah Siswa Kelas VIII SMP NEGRI 6 KOTA Bima. ORYZA (Jurnal Pendidikan Biologi), 8(2), 40-46.

Gunawan, I. 2017. Indonesia Curriculum 2013: Instructional management, obstacles faced by teachers in implementation and the way forward. 3rd International Conference on Education and Training (ICET 2017).

Gusty, S. 2020. Belajar Mandiri: Pembelajaran

Daring di Tengah Pandemi Covid-19. Yayasan Kita Menulis.

Kapasia, N., Paul, P., Roy, A., Saha, J., Zaveri, A., Mallick, R., Barman, B., Das, P., \& Chouhan, P. 2020. Impact of lockdown on learning status of undergraduate and postgraduate students during COVID-19 pandemic in West Bengal, India. Children and Youth Services Review, 116, 105194.

Kurniaman, O., \& Noviana, E. 2017. Penerapan Kurikulum 2013 dalam meningkatkan keterampilan, sikap, dan pengetahuan. Primary: Jurnal Pendidikan Guru Sekolah Dasar, 6(2), 389-396

Masrokhah, M. 2020. Evaluasi Implementasi Kurikulum 2013 Dalam Pembelajaran Online Selama Masa Pandemi Covid-19 Di Sdn Bintoro 5 Kabupaten Demak.

Radha, R., Mahalakshmi, K., Sathis Kumar, V., \& Saravanakumar, A. R.. E-Learning During Lockdown of Covid-19 Pandemic: A Global Perspective. International Journal of Control and Automation, 13(4), (2020), 1088-1099

Sudarsana, I. K. 2020. Covid-19: Perspektif Pendidikan. Yayasan Kita Menulis

Wahyono, P., Husamah, H., \& Budi, A. S.. Guru profesional di masa pandemi COVID-19: Review implementasi, tantangan, dan solusi pembelajaran daring. Jurnal Pendidikan Profesi Guru, l(1), (2020), 51-65. 